\title{
Waste Heat and Wastewater Recovery in Textile Processing Industry: A Case Study of Adopted Practices
}

\author{
Tanveer Ahmed Gadhi ${ }^{1 a}$, Imran Ali ${ }^{2}$, Rasool Bux Mahar ${ }^{1 b}$, Hubdar Ali Maitlo ${ }^{3}$, \\ Najeebullah Channa ${ }^{1 \mathrm{c}}$
}

RECEIVED ON 23.09.2019, ACCEPTED ON 15.09.2020

\begin{abstract}
Textile wet processes dispose of huge amounts of water and energy in the form of hot wastewater and exhaust gas emissions. A significant amount of water and energy can be conserved by adopting various waste heat and water recovery methods, such as the use of heat exchanger, recycling hot wastewater, steam condensate, and cooling water recovery and reuse. In this study, various waste energy and water conservation methods are summarized to highlight their importance for water and energy conservation. For practical consideration, a detailed assessment of such practiced methods was done in one textile processing industry. The obtained results revealed that a high amount of energy and water could be conserved by adopting various waste heat and water recovery methods, with the advantage of reducing environmental pollution while minimizing the consumption of energy and water.
\end{abstract}

Keywords: Waste Heat Recovery, Textile Wastewater, Wastewater Treatment and Reuse.

\section{INTRODUCTION}

$\mathrm{W}$ aste heat is resulted from a process of fuel combustion, chemical reaction, and hot liquid process and discharged in the environment in the form of exhaust emission and hot wastewater without being recovered for practical application [1,2]. The recovery and usage of waste heat require needless efforts to modify the conventional industrial processes or machinery, to cut process costs and further to control environment pollution. For the intended use and for value addition in textile products, various wet processes are carried out, such as bleaching, mercerizing [3], dyeing, printing, washing, and finishing [4, 5]. All these processes are energy and water-intensive and consume a huge amount of energy and water [6-8]. Water is used as a transport medium to perform wet processes, while energy is needed for process heating, either in the form of saturated steam or in the form of hot air, to increase the kinetics of the mentioned processes. During these processes, a huge amount of waste heat and hot wastewater is generated and discharged into the waste streams, that could be reutilized with an adaptation of various cleaner production practices such as the use of waste heat exchangers at process outlet to recover heat for heating the freshwater [9, $10]$.

In the textile wet processing industry, the main source of energy input/fuel is the combustion of natural gas for the generation of electricity, saturated steam

${ }^{1}$ US-Pakistan Centre for Advanced Studies in Water, Mehran University of Engineering and Technology, Jamshoro, Sindh, Pakistan. Email: ${ }^{a}$ tanveer.uspcasw@ faculty.muet.edu.pk, ${ }^{b}$ rbmahar.uspcasw@ faculty.muet.edu.pk, cnajeebchanna@outlook.com

${ }^{2}$ Department of Environmental Sciences, Sindh Madersatul Islam University, Karachi, Sindh, Pakistan. Email: imran.engineer41@gmail.com (Corresponding Author)

${ }^{3}$ Department of Energy and Environment Engineering, Dawood University of Engineering and Technology, Karachi, Sindh, Pakistan. Email: hubdar_ali39@yahoo.com

This is an open access article published by Mehran University of Engineering and Technology, Jamshoro under CC BY 4.0 International License. 
production, to perform drying and curing processes [11]. The electricity provides power to operate the machines, and saturated steam is used for process water heating, fabric steaming and for dryers heating. Considering the main focus on the production, the waste streams of these processes often neglected, without pondering their significance in recovering energy and water from such streams. In brief, the main sources of such waste heat energy and hot wastewater are [6]:

- Exhaust emissions from the chimneys of steam boilers, power turbines, and generators, drying and curing processes.

- Hot wastewater discharged from textile processes and washing baths.

- Water used for cooling (cooling water) of power generators, radiators, process equipment, cooling cylinders, and other plants, as their cooling is necessary for continuous operations.

- Steam condensate resulted after condensation of saturated steam i.e. when the latent heat of steam is utilized and condensed into pure hot water.

It is estimated that approximately half of the total industrial energy consumption is discharged as waste heat. However, implementation of simple modification at disposal streams could help in recovering and reusing this waste heat without affecting any process or quality of the product [12]. In addition, such implementations are considered cleaner production practices in textile processing [13]. Moreover, the consideration of these practices is now becoming necessary, because of the significance of energy and water conservation, due to scarcity and insufficiency to fulfill future demands $[14,15]$. Furthermore, increased energy cost and high industrial competition have highlighted the importance of adopting efficient energy and water management in the industrial processes [16], along with are useful to reduce environmental pollution $[17,18]$.

In this work, different waste streams of the textile processing industry are discussed in detail in terms of the type and temperature of each stream. Moreover, various Waste Heat Recovery (WHR) methods are overviewed in detail. Besides, to show the practical viability of such methods and resulted in advantages i.e. the recovered amount of wasted energy and water, assessment of applied WHR methods and environmental management practices was done in one of the leading textile mills in Pakistan. Such assessment includes continuous monitoring of the cooling water, steam condensate, on-site water reuse, heat exchangers and exhaust emissions to estimate and calculate the amount of recovered energy and reused wastewater, with the adoption of WHR methods.

\section{OVERVIEW OF THE RECOVERY METHODS}

\subsection{Water and Energy Recovery}

In textile wet processing, water is the main input to perform bleaching, mercerizing, dyeing, printing, washing, and finishing processes [19]. Moreover, water is used for saturated steam production and cooling of electric generators and hot equipment. For the mentioned processes, hot water is needed, i.e. up to $80-90{ }^{\circ} \mathrm{C}$, which after the application is directly disposed of as hot wastewater. To reduce the waste generation at the source the best approach is the onsite reuse of the hot wastewater within a similar application [20,21]. This could be achieved with collection and screen filtration of the hot wastewater from one stage of the process and its reuse in the other stage of the same process, as shown in Fig. 1. By adopting this method, both water and energy could be recovered, and their consumption could be reduced. While waste energy of the disposed of hot wastewater could be further recovered by employing a heat exchanger at the final outlet, through which the incoming fresh feed-water is brought in indirect contact to allow heat transfer between hot wastewater and fresh feed-water as shown in Fig. 1.

\subsubsection{Cooling Water Heat Recovery}

Cooling of equipment and plants is a common industrial practice, in which cooling water is used to retreat heat from certain equipment through conduction, for their smooth performance and continuous operation [22]. In common practice, the heat of cooling water is wasted at cooling towers and brought back in cooling operation under a closed cyclic system, as shown in the scheme in Fig. 2. 


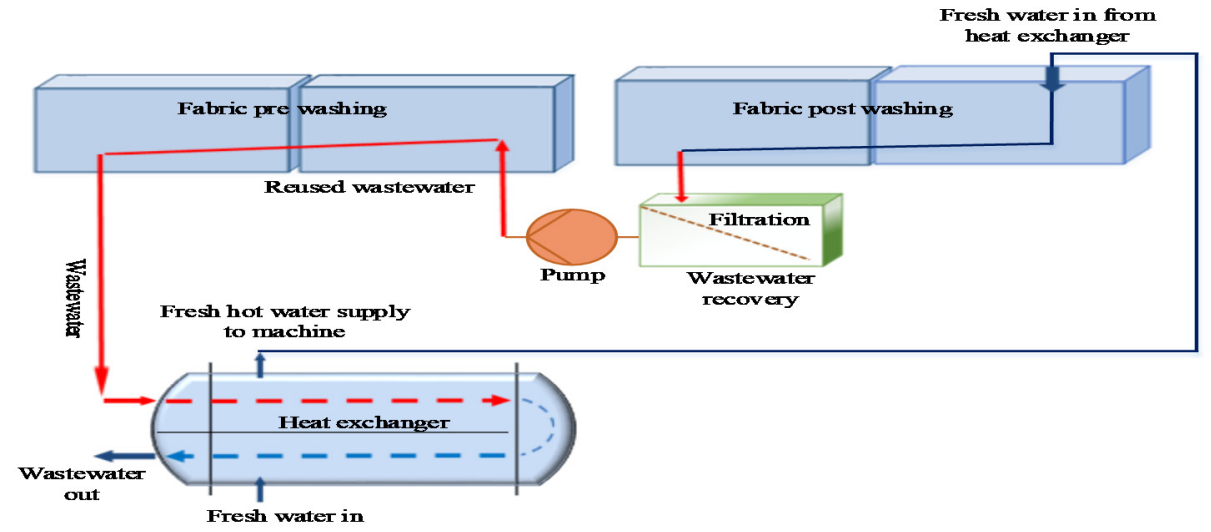

Fig. 1: Water recycling and on-site water reuse at the wet-processing machine with water heat exchanger

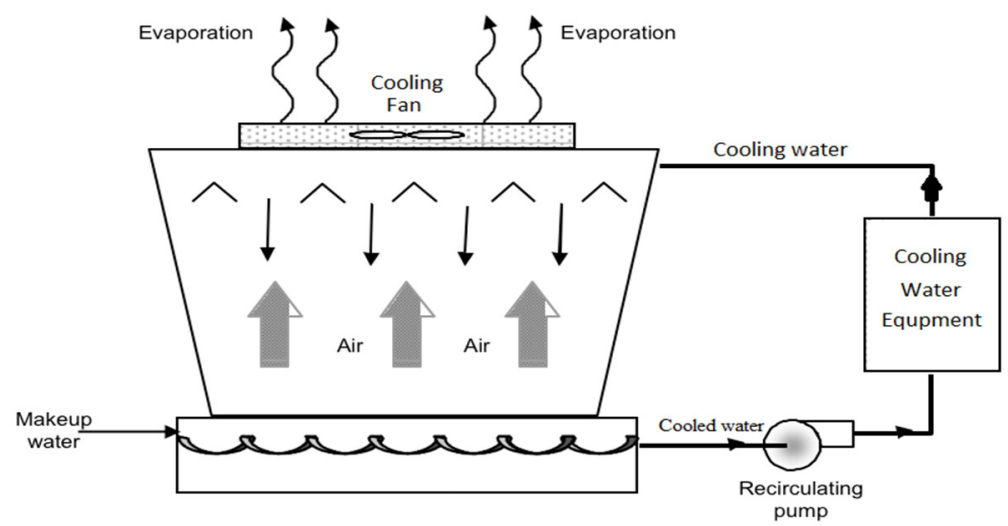

Fig. 2. Schematic diagram of cooling tower

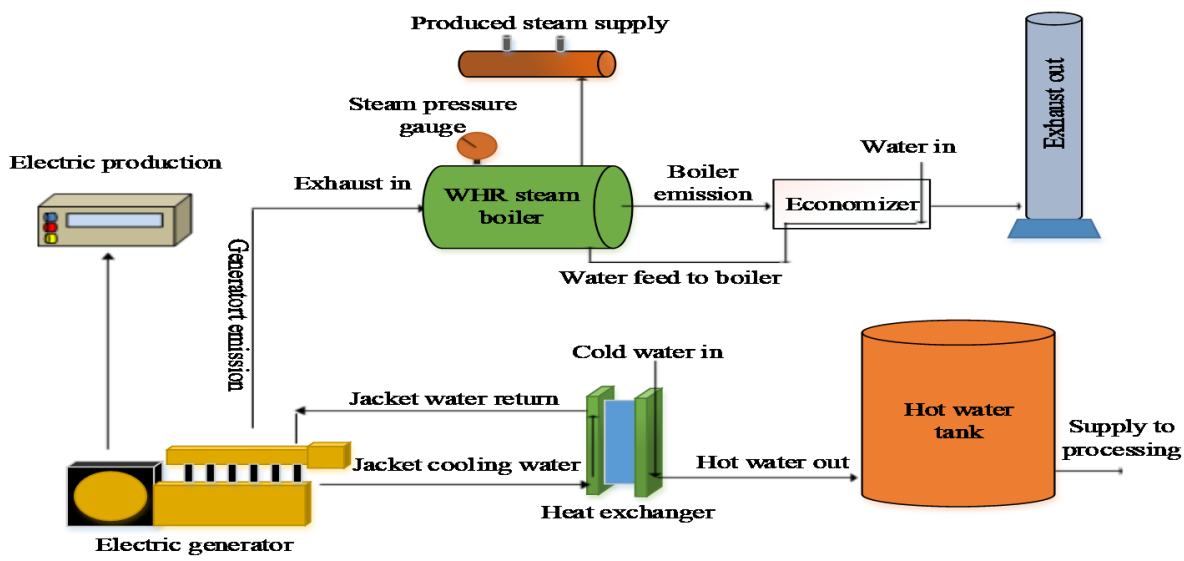

Fig. 3: Cooling water heat recovery from electric generator jacket water, with steam generation from Whr Boiler and Economizer.

However, the heat in cooling water could be recovered with the use of heat exchanger to heat the fresh water before supply to process or machines, as shown in the scheme in Fig. 3 showing the method of heat exchange between cooling water of power generator and process freshwater.

\subsubsection{Steam Condensate Recovery}

A steam boiler produces saturated steam, which is mainly used for heating process water. The produced statured steam is either directly injected or indirectly utilized by passing the steam inside a plate or tubes (to Mehran University Research Journal of Engineering and Technology, Vol. 40, No. 3, July 2021 [p-ISSN: 0254-7821, e-ISSN: 2413-7219] 
heat the surrounded process water) [23]. The difference in both types is shown in Fig. 4(a-b). During indirect usage, the latent heat is utilized, and steam is condensed into freshwater commonly termed as hot steam condensate. This steam condensate being hot and pure water is the important source of steam boiler feed-water. Therefore it is recovered from various processes through steam condensate return lines and further supplied to the steam boilers feed-water system, as shown in Fig. 5. Most of the washing baths/chambers and steam dryers are heated using indirect methods and generate a significant amount of condensate.
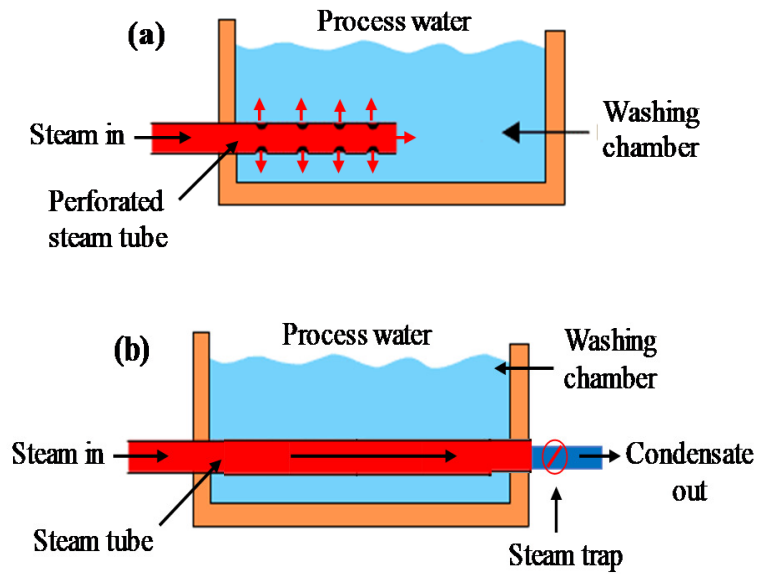

Fig. 4: Types of steam usage: (a) Direct steam use, and (b) Indirect steam use.

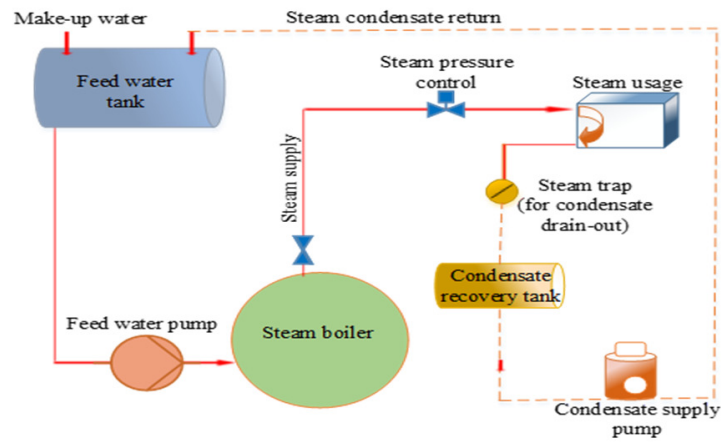

Fig. 5: Schematic diagram of steam condensate recovery

\subsection{Heat Recovery from Exhaust Emissions}

The main sources of waste heat from industries include exhaust emissions from power plants, steam boilers, and other curing machines. The average heat efficiency of the conventional power plant is around $35-40 \%$ [24], while the remaining energy is lost into the environment, in the form of exhaust emissions, and conduction and radiation losses [25]. The combustion of power turbine, power generator, and steam boilers released high amount of exhaust heat i.e. in the ranges 250-580 ${ }^{\circ} \mathrm{C}$, therefore recovered heat from such streams have significance. Some of the adopted WHR methods on such exhaust streams are discussed in upcoming sections.

\subsubsection{Waste Heat Recovery Boilers}

The exhaust emissions could be used for the production of saturated steam by employing the waste heat recovery boiler, also termed as a smoke tube steam boiler, already in practice for various applications [26, 27]. Generally, a smoke tube WHR boiler contains a web of parallel tubes, and inside these, the exhaust gasses are passed. Initially, the water is heated (outside the tubes), and then water vapor is pressurized for the production of saturated steam. Such a smoke tube boiler can be placed at the exhaust outlet of power generator or turbines, as shown in the scheme in Fig. 3.

\subsubsection{Economizers}

The steam boiler running on natural gas $\left(\mathrm{CH}_{4}\right) /$ fuel produced exhaust emissions of the medium temperature range $\left(180-265^{\circ} \mathrm{C}\right)$ [28]. For recovery of waste heat from the emissions of a steam boiler, an economizer could be employed at a boiler outlet for exchanging its contribution to the incoming boiler feed-water [29], as shown in the scheme given in Fig. 3. This economizer has the same working principle as of heat exchanger (discussed earlier), but the exhaust heat source is in the gas phase [30]. By adopting this practice, the thermal efficiency of the steam boiler could be improved along with the reduction of boiler fuel consumption.

\section{EXPERIMENTAL ASSESSMENT}

To summarize the practical viability of earlier discussed WHR methods, a detailed assessment was made at Yunus Textile Mills (YTM), Pakistan, where it is known as the largest exporter of textile goods made in the country. YTM has a production and processing capacity of 100 million meters of textile fabric per year. YTM is equipped with continuous 
textile wet processing machines (machines details and processes layouts are given in Fig. 6) and has its power plant for electricity generation and steam boilers for saturated steam production. Details of the power and steam generation equipment, textile wet processing machines, and perform processes in YTM are given in Table 1-2. Most of the WHR methods discussed in earlier sections are adopted by YTM, the summarized information, including the sources of generated waste heat, wastewater, and adopted WHR method along with environmental benefits associated to each recovery method, is given in Table 3.

The analyses of recovered waste heat and water from the adopted methods were made by (i) thermal assessment of the amount of energy recovered/transferred from wastewater with monitoring temperature changes at the inlets and outlets of WHR equipment i.e. heat exchanger, economizer etc., (ii) quantitative assessment of the amount of the water and steam after monitoring and analysis of their consumption from mounted flow meters at the water and steam lines and (iii) quantitative assessment of the steam condensate recovery after monitoring and analyzing the amount of recovered condensate from the mounted flow meter at condensate return lines.

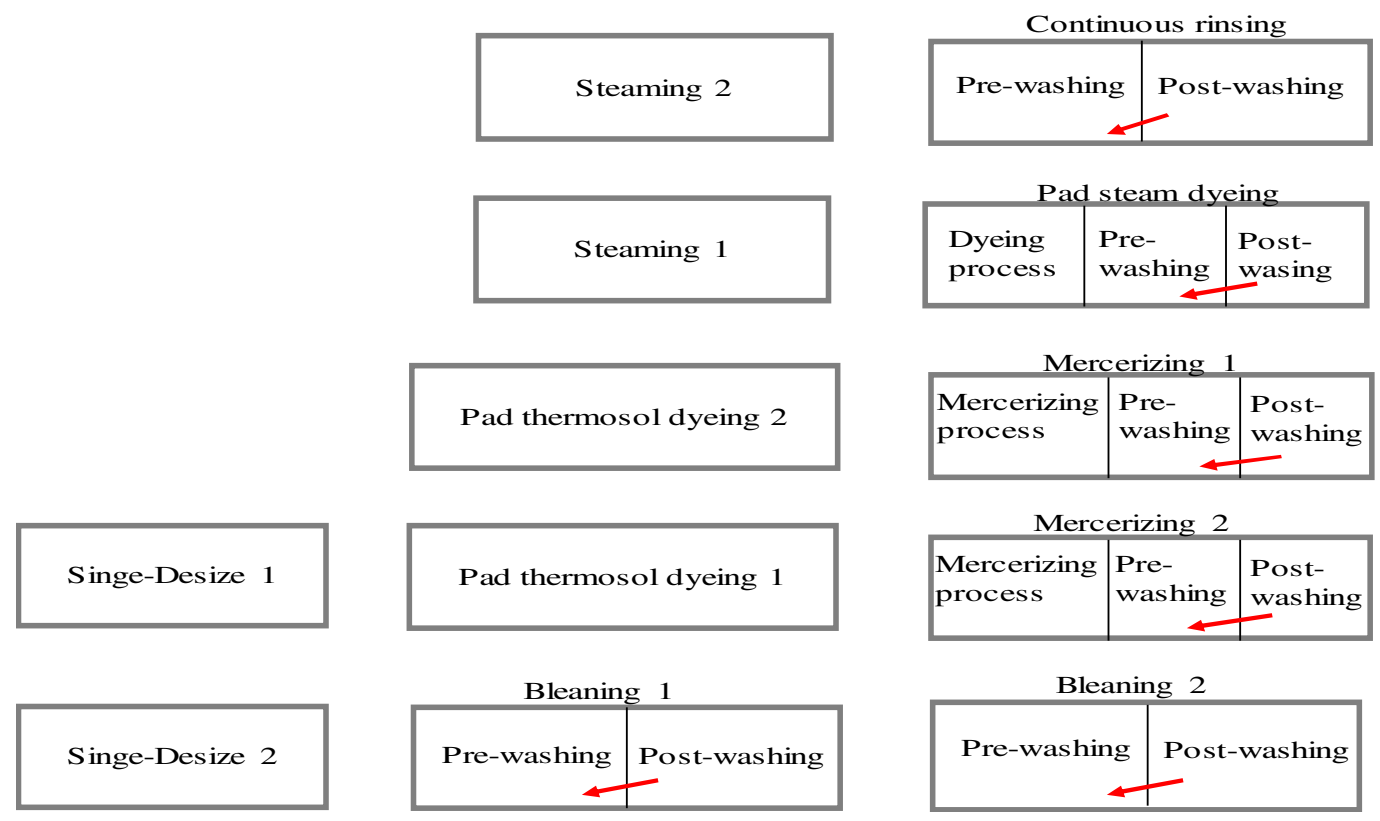

Fig. 6: Textile Wet-Processing machines and processes layout at Yunus Textile Mills. Red arrows are related to the heat flux and hot wastewater flow.

\begin{tabular}{|c|c|c|c|c|}
\hline \multicolumn{5}{|c|}{ Table 1: Details of YTM power and steam generation equipments } \\
\hline Details & Quantity & Made & Purpose & Production capacity \\
\hline Gas power turbine & 2 & Solar Caterpillar & Power generation & $1 \mathrm{MW}$ each \\
\hline Engine 3516C & 1 & Caterpillar & Power generation & $1.4 \mathrm{MW}$ \\
\hline Engine 3516A & 1 & Caterpillar & Power generation & $1 \mathrm{MW}$ \\
\hline Gas boiler 1 & 1 & Descon & Steam generation & 10 ton h$^{-1}$ \\
\hline Gas boiler 2 \\
$\begin{array}{c}\text { WHR smoke tube } \\
\text { boiler 1 }\end{array}$ & 1 & DDFC & Steam generation & 7 ton h$^{-1}$ \\
\hline $\begin{array}{c}\text { WHR smoke tube } \\
\text { boiler 2 }\end{array}$ & 1 & DDFC & Steam generation & 8 ton h$^{-1}$ \\
\hline CRP & 1 & DDFC & Steam generation & 1.2 ton h$^{-1}$ \\
\hline \multicolumn{2}{|c|}{ MW = megawatt, WHR = waste heat recovery, CRP = caustic recovery plant } \\
\hline
\end{tabular}

Mehran University Research Journal of Engineering and Technology, Vol. 40, No. 3, July 2021 [p-ISSN: 0254-7821, e-ISSN: 2413-7219] 


\begin{tabular}{|c|c|c|c|c|}
\hline \multicolumn{5}{|c|}{ Table 2: Details of YTM Wet-Processing Machines. } \\
\hline Details & Quantity & Made by & Purpose & $\begin{array}{l}\text { Production capacity } \\
\qquad\left(10^{3} \mathrm{~m} \mathrm{~d}^{-1}\right)\end{array}$ \\
\hline $\begin{array}{l}\text { Singe- } \\
\text { desize }\end{array}$ & 2 & Osthoff & $\begin{array}{l}\text { Singing: the direct burning flame is used for } \\
\text { fabric surface treatment } \\
\text { Desizing: enzymes are used for the removal } \\
\text { of starch }\end{array}$ & 260 \\
\hline Bleaching & 2 & Goller & $\begin{array}{l}\text { Initial treatment of textile fabric for the } \\
\text { removal of natural and artificial impurities }\end{array}$ & 250 \\
\hline Mercerize & 1 & Goller & $\begin{array}{l}\text { Textile Treatment with caustic to improve } \\
\text { fabric absorbency }\end{array}$ & 75 \\
\hline $\begin{array}{c}\text { Pad steam } \\
\text { dyeing }\end{array}$ & 1 & Goller & Dyeing and coloring of fabric & 65 \\
\hline $\begin{array}{c}\text { Pad } \\
\text { thermosol } \\
\text { dyeing }\end{array}$ & 2 & Monforts & Dyeing and coloring of fabric & 80 \\
\hline $\begin{array}{c}\text { Continuous } \\
\text { rinsing }\end{array}$ & 1 & Kuster & $\begin{array}{c}\text { Textile fabric washing after dyeing and } \\
\text { printing }\end{array}$ & 70 \\
\hline Steaming & 2 & Arioli/salvade & Steam treatment of printed fabric to fix color & 140 \\
\hline
\end{tabular}

\begin{tabular}{|c|c|c|}
\hline \multicolumn{3}{|c|}{ Table 3: Details of YTM heat recovery sources and WHR methods with environmental and economic advantages } \\
\hline Machine/source of heat energy & WHR method & Potential advantages \\
\hline $\begin{array}{c}\text { Cooling water from singe-desize } \\
\text { burners, cooling cylinders, power } \\
\text { engine, and caustic recovery plant }\end{array}$ & $\begin{array}{c}\text { Cooling water collection and } \\
\text { supply to rinsing and washing } \\
\text { processes }\end{array}$ & $\begin{array}{c}\text { Conservation of water and energy. } \\
\text { Resource sustainability due to reduced } \\
\text { emission and low steam consumption. }\end{array}$ \\
\hline $\begin{array}{c}\text { The heat from wastewater after } \\
\text { bleaching, mercerize, pad steam } \\
\text { dyeing, and continuous rinsing }\end{array}$ & $\begin{array}{c}\text { Heat transfer from discharged } \\
\text { wastewater to increase the } \\
\text { temperature of fresh process } \\
\text { water }\end{array}$ & $\begin{array}{c}\text { Conservation of energy and low } \\
\text { temperature of final discharged water } \\
\text { reduced oxygen depletion }\end{array}$ \\
\hline $\begin{array}{c}\text { Bleaching and mercerize machines } \\
\text { post washing water recovery and } \\
\text { reuse }\end{array}$ & $\begin{array}{c}\text { Post washing processes water } \\
\text { recovery and reuses in pre- } \\
\text { washing }\end{array}$ & Conservation of water and steam. \\
\hline $\begin{array}{c}\text { Steam condensate generated from } \\
\text { heating baths and various processes }\end{array}$ & $\begin{array}{c}\text { Recovery and supply to the } \\
\text { steam boiler feed-water system. }\end{array}$ & $\begin{array}{c}\text { Conservation of water and energy. } \\
\text { Low fuel consumption for steam } \\
\text { production. }\end{array}$ \\
\hline $\begin{array}{c}\text { Exhaust emissions generated by two } \\
\text { power turbines and generators }\end{array}$ & $\begin{array}{c}\text { Exhaust emission of turbines } \\
\text { and generators are used for } \\
\text { steam generation or heating } \\
\text { process water }\end{array}$ & $\begin{array}{c}\text { Low temperature and reduced exhaust } \\
\text { emissions }\end{array}$ \\
\hline $\begin{array}{c}\text { Two gas fuel steam boilers and two } \\
\text { smoke tube WHR steam boilers }\end{array}$ & $\begin{array}{c}\text { Pre-heated feed-water supply by } \\
\text { means of heat transfer from } \\
\text { exhaust emissions of the steam } \\
\text { boiler }\end{array}$ & $\begin{array}{c}\text { Low fuel consumption by avoiding } \\
\text { excess water heating. Increase in boiler } \\
\text { efficiency }\end{array}$ \\
\hline
\end{tabular}

Before monitoring and analyzing each source, the monitoring instruments, i.e. temperature gauges, flowmeters of steam, water, and condensate, were calibrated. The frequency of the monitored data was twice a day and remained to continue up to 60 days duration. For the final assessment, an average of recorded temperatures and flows was considered. The amount of recovered/transferred heat was determined by taking the difference of the inlets and outlet temperatures that were applied in equation (1), along with the recorded average quantity of water, to calculate the amount of effective recovered energy.

$\mathrm{Q}=\mathrm{mC}_{\mathrm{p}} \Delta \mathrm{T}$

where $\mathrm{Q}$ is the heat energy in $\mathrm{kJ}, \mathrm{m}$ is mass or quantity or amount in $\mathrm{kg}$ or $\mathrm{L}, \mathrm{C}_{\mathrm{p}}$ is the specific heat of the water $4.184 \mathrm{~kJ} \mathrm{~kg}^{-1}{ }^{\circ} \mathrm{C}^{-1}$, and $\Delta \mathrm{T}$ is the temperature 
difference in ${ }^{\circ} \mathrm{C}$. The obtained values in $\mathrm{kJ}$ were converted in Millions British Thermal Unit (MBTU), by dividing the obtained values by $1.055 \times 10^{5}$.

\section{RESULTS AND DISCUSSION}

\subsection{Cooling Water Recovery}

Table 4 shows the amount of recovered cooling water and energy from different sources, which were calculated from the recorded average temperatures and quantities. The recovered amount of cooling water and heat was low, from cooling cylinders of processing machines because these processes need less amount of water and retreated heat is also low due to continuous cooling water flow. While in the case of cooling of the power generator and caustic recover plant (CRP) condenser, where the retreated heat and amount of recovered cooling water were higher.

\subsection{Heat Exchangers}

Table 5 shows the amount of recovered heat (for heating the freshwater) with the use of heat exchangers at various sources. The heat gain $(\Delta T)$ from shell and tube type heat exchanger (shown in Fig. 1) was in the range of $18-25{ }^{\circ} \mathrm{C}$, but for plate type heat exchanger (located at one of the continuous rinsing machines) the heat gain was higher, as it allowed good contact of inlet freshwater with exited hot wastewater, therefore, resulted in higher heat transfer than shell and tube type heat exchanger. The recovered amount of heat from wastewater revealed that significant energy is being recovered in heating inlet freshwater, which eventually reduced the excess use of saturated steam.

\subsection{On-Site Water Reuse}

Assessment of on-site water reuse was made at two bleachings, and one mercerize machines, where the collected water after final-washing stages were recovered and reused in pre-washing stages (refer Fig. 1). The analysis was done by taking the temperature difference of reused water, and freshwater and the recorded amount of reused water, and the calculated amounts are given in Table 6 . The quantity of reused water of bleaching-1 machine was higher than bleaching-2 and mercerize machines, because of its higher textile processing capacity and high amount of generated wastewater.

\subsection{Steam Condensate Recovery}

Energy and water recovery from steam condensate were assessed by analyzing the average temperature and quantities of recovered steam condensate from various indirect steam usage sources, including two

\begin{tabular}{|c|c|c|c|c|c|}
\hline \multicolumn{5}{|c|}{ Table 4: Assessment of recovered heat energy from cooling water } \\
\cline { 2 - 5 } Energy source/machine & $\begin{array}{c}\text { Freshwater } \\
\mathrm{m}^{3} \mathrm{~d}^{-1}\end{array}$ & In & Out & $\Delta \mathrm{T}$ & year $^{-1}$ \\
\hline Singe-desize 1 & 60.5 & 20.0 & 39.5 & 19.5 & $1,685.2$ \\
\hline Singe-desize 2 & 60.0 & 20.2 & 39.0 & 18.8 & $1,611.2$ \\
\hline Pad thermosol dyeing 1 & 29.5 & 20.5 & 40.3 & 19.8 & 834.3 \\
\hline Pad thermosol dyeing 2 & 30.5 & 20.3 & 39.8 & 19.5 & 849.5 \\
\hline Power generator jacket & 220.8 & 21.0 & 75.2 & 54.2 & $17,094.2$ \\
\hline CRP condenser & 312.2 & 21.5 & 70.1 & 48.6 & $21,673.0$ \\
\hline Total & 713.5 & & & & $43,747.4$ \\
\hline
\end{tabular}

\begin{tabular}{|c|c|c|c|c|c|}
\hline & essment of $r$ & at ene & n heat & gers & \\
\hline \multirow{2}{*}{ Energy source/machine } & \multirow{2}{*}{$\begin{array}{c}\text { Freshwater } \\
\mathrm{m}^{3} \mathrm{~d}^{-1}\end{array}$} & \multicolumn{3}{|c|}{ Freshwater ${ }^{\circ} \mathrm{C}$} & \multirow{2}{*}{$\begin{array}{c}\text { MMBTU } \\
\text { year }^{-1}\end{array}$} \\
\hline & & In & Out & $\Delta \mathrm{T}$ & \\
\hline Bleaching 1 & 280.1 & 20.2 & 40.5 & 20.3 & $8,121.3$ \\
\hline Bleaching 2 & 180.0 & 21.0 & 39.2 & 18.2 & $4,679.4$ \\
\hline Mercerize 2 & 139.9 & 20.5 & 42.8 & 22.3 & $4,456.9$ \\
\hline Pad steam dyeing & 146.2 & 20.7 & 45.5 & 24.8 & $5,186.1$ \\
\hline Continuous rinsing & 148.8 & 20.0 & 55.1 & 35.1 & $7,460.4$ \\
\hline Total & 895.2 & & & & $29,904.1$ \\
\hline
\end{tabular}




\begin{tabular}{|c|c|c|c|c|c|}
\hline \multicolumn{5}{|c|}{ Table 6: Assessment of recovered heat energy from On-Site water reuse } \\
\hline $\begin{array}{c}\text { Energy } \\
\text { source/machine }\end{array}$ & $\begin{array}{c}\text { Reused } \\
\text { water } \\
\mathrm{m}^{3} \mathrm{~d}^{-1}\end{array}$ & Freshwater ${ }^{\circ} \mathrm{C}$ & Reused water ${ }^{\circ} \mathrm{C}$ & $\Delta \mathrm{T}^{\circ} \mathrm{C}$ & MMBTU year ${ }^{-1}$ \\
\hline Bleaching 1 & 100.8 & 20.7 & 81.4 & 60.7 & $8,739.7$ \\
\hline Bleaching 2 & 40.8 & 21.2 & 78.9 & 57.7 & $3,362.7$ \\
\hline Mercerize 2 & 36.0 & 20.1 & 75.3 & 55.2 & $2,838.5$ \\
\hline Total & 177.6 & & & & $14,940.9$ \\
\hline
\end{tabular}

bleachings, mercerize, pad steam dyeing, continuous rinse, and two steaming machines. The recovered energy from steam condensate is given in Table 7 , which was calculated after taking the difference of the steam condensate and the average temperature of fresh boiler make-up water. In YTM, average steam consumption was 505 ton $\mathrm{d}^{-1}$ and steam condensate recovery from all sources is about $56.7 \%$ of the total steam consumption because some of the processes in YTM utilized direct injection of steam for process heating i.e. at steamers of bleaching, washing baths, and pad steam dyeing machines. The total amount of saved water through the recovery of reused water (Table 6) and steam condensate (Table 7) was about $167,076 \mathrm{~m}^{3}$ year $^{-1}$.

\subsection{Heat Recovery from Exhaust Emission}

For the assessment of the exhaust emissions released from steam boilers, electric generators, and turbines, the temperature of emissions (released after combustion operation) were recorded from each source at the inlet and outlet of the employed economizers and WHR smoke-tube steam boilers. Amount of recovered heats are given in Tables 8-9, calculated from the produced saturated steam from smoke-tube WHR boilers and pre-heating of the boiler feed-water through economizer. Steam production and economizer pre-heating of smoke-tube WHR boiler-1 were higher than boiler- 2 i.e. around $518{ }^{\circ} \mathrm{C}$ and flow of generated emissions were higher from two power turbines, compared to one power generator emissions applied at smoke-tube WHR boiler 2. While recovered heat from the economizer at gas fuel boiler-1 was higher than gas boiler-2, due to its higher capacity of steam production $\left(10\right.$ ton $\left.\mathrm{h}^{-1}\right)$ and temperature of released emissions at the economizer inlet, as observed in the given Table 9.

\begin{tabular}{|c|c|c|c|c|c|}
\hline \multicolumn{7}{|c|}{ Table 7: Assessment of recovered heat energy from steam condensate } \\
\hline $\begin{array}{c}\text { Energy } \\
\text { source/machine }\end{array}$ & Condensate $\left(\mathrm{m}^{3} \mathrm{~d}^{-1}\right)$ & Condensate ${ }^{\circ} \mathrm{C}$ & Make-up water ${ }^{\circ} \mathrm{C}$ & $\Delta \mathrm{T}{ }^{\circ} \mathrm{C}$ & MMBTU $\left(\right.$ year $\left.^{-1}\right)$ \\
\hline Bleaching 1 & 102.6 & 99.5 & 20.4 & 79.1 & $11,592.4$ \\
\hline Bleaching 2 & 45.9 & 98.8 & 20.3 & 78.5 & $5,146.7$ \\
\hline Mercerize 2 & 54.5 & 97.5 & 20.5 & 77.0 & $5,994.3$ \\
\hline Pad steam dyeing & 46.9 & 99.2 & 20.1 & 79.1 & $5,299.1$ \\
\hline Continuous rinsing & 21.6 & 98.1 & 20.4 & 77.7 & $2,397.3$ \\
\hline Steaming 1 & 7.8 & 97.6 & 20.2 & 77.4 & 862.4 \\
\hline Steaming 2 & 7.2 & 98.6 & 20.4 & 78.5 & 807.3 \\
\hline Total & 286.5 & & & & $32,099.4$ \\
\hline
\end{tabular}

\begin{tabular}{|c|c|c|c|c|}
\hline \multirow[b]{2}{*}{ WHR boilers } & \multirow{2}{*}{\multicolumn{2}{|c|}{ Exhaust emission ${ }^{\circ} \mathrm{C}$}} & \multirow{2}{*}{$\begin{array}{l}\text { Steam } \\
\text { ton } \mathrm{d}^{-1}\end{array}$} & \multirow{2}{*}{$\begin{array}{c}\text { MMBTU } \\
\text { year }^{-1}\end{array}$} \\
\hline & Inlet & & & \\
\hline $\begin{array}{l}\text { Smoke-tube WHR boiler 1 (at exhaust } \\
\text { outlet of two power Turbines) }\end{array}$ & 518.2 & 265.1 & 189.6 & $134,338.2$ \\
\hline $\begin{array}{c}\text { Smoke-tube WHR boiler } 2 \\
\text { (at exhaust outlet of power generator) }\end{array}$ & 480.5 & 182.2 & 24.5 & $17,344.9$ \\
\hline Total & & & 214.1 & $151,683.1$ \\
\hline
\end{tabular}




\begin{tabular}{|c|c|c|c|c|c|c|c|}
\hline \multicolumn{8}{|c|}{ Table 9: Assessment of recovered heat energy from boiler economizers } \\
\hline \multirow{2}{*}{ Economizers } & \multicolumn{2}{|c|}{ Boiler emission ${ }^{\circ} \mathrm{C}$} & \multirow{2}{*}{$\begin{array}{c}\text { Feed-water } \\
\mathrm{m}^{3} \mathrm{~d}^{-1}\end{array}$} & \multicolumn{3}{|c|}{ Feed-water ${ }^{\circ} \mathrm{C}$} & \multirow{2}{*}{$\begin{array}{c}\text { MMBTU } \\
\text { year }^{-1}\end{array}$} \\
\hline & In & Out & & In & Out & $\Delta \mathrm{T}$ & \\
\hline Gas boiler 1 & 235.2 & 160.1 & 237.6 & 98.5 & 121.4 & 22.9 & $7,772.0$ \\
\hline Gas boiler 2 & 180.1 & 131.2 & 50.4 & 98.3 & 113.1 & 14.8 & $1,065.5$ \\
\hline $\begin{array}{c}\text { Smoke-tube } \\
\text { WHR boiler } 1\end{array}$ & 265.1 & 155.4 & 192.2 & 98.4 & 140.2 & 41.8 & $11,478.1$ \\
\hline $\begin{array}{c}\text { Smoke-tube } \\
\text { WHR boiler } 2\end{array}$ & 182.2 & 136.3 & 25.2 & 98.5 & 108.3 & 9.78 & 352.0 \\
\hline Total & & & 505.4 & & & & $20,667.6$ \\
\hline
\end{tabular}

YTM uses natural gas $\left(\mathrm{CH}_{4}\right)$ as fuel, and the estimated saving of $\mathrm{CH}_{4}$ was around 293,043 MMBTU year'-1. According to US EPA, the $\mathrm{CO}_{2}$ emissions coefficient is $53.1 \mathrm{Kg} \mathrm{CO}_{2}$ per MMBTU of $\mathrm{CH}_{4}$ [31]. Therefore, the overall associated environmental benefits in terms of $\mathrm{CO}_{2}$ reduction was around 15,561 ton year ${ }^{-1}$.

\section{CONCLUSIONS}

In the textile wet processing industry, a huge amount of wasted energy and water could be conserved by implementing various WHR methods that could reduce the fuel consumption in heating the process water and for steam production and eventually could reduce environmental pollution by minimizing the emissions level. The use of heat exchanger at outlets of the textile process and stacks of the power turbines and boilers could decrease the temperature of the waste streams i.e. wastewater and exhaust emissions. The performed assessment of adopted WHR methods at YTM confirmed the suitability and practicability of such methods for energy recovery from reused water, cooling water, steam condensate, wastewater and exhaust emissions of steam boilers and power plant. Estimated water conservation through water reuse and steam condensate recovery was around $167,076 \mathrm{~m}^{3}$ year ${ }^{-1}$. YTM uses $\mathrm{CH}_{4}$ as a fuel, and an overall estimated saving of methane was around 293,043 MMBTU year ${ }^{-1}$ and estimated $\mathrm{CO}_{2}$ reduction was around 15,561 ton year $^{-1}$, with the utilization of various WHR methods i.e. use of cooling water, steam condensate, heat exchangers, reuse of hot wastewater and exhaust emissions.

\section{ACKNOWLEDGMENTS}

The authors acknowledge the technical support of Mr. Munir Badar, Manager Environment, Mr. Rizwan Younus, Technical Director, from Yunus Textile
Mills, Karachi. This study was supported by one of the research projects funded by the United States Government and the American people through the United States Agency for International Development (USAID) and USPCAS-W, MUET. The contents are the sole responsibility of the authors and do not necessarily reflect the views of USAID or the United States Government.

\section{REFERENCES}

1. Nwosu P., "Condenser-side integration of a simple solar-type waste heat recovery device in a thermal plant", Journal of Cleaner Production, Vol. 157, pp. 333-341, 2017.

2. Kapil A., Bulatov I., Smith R., Kim J.-K., "Sitewide low-grade heat recovery with a new cogeneration targeting method", Chemical Engineering Research and Design, Vol. 90, no. 5, pp. 677-689, 2012.

3. Zahid B., Faisal S., Siddique H., "Analysis of Caustic Soda of Different Manufacturers in Pakistan for Mercerization of Cotton Textiles", Mehran University Research Journal of Engineering and Technology, Vol. 36, No. 4, pp. 857-866, October 2017.

4. Ali I., Kim S.-R., Kim S.-P., Kim J.-O., "Recycling of textile wastewater with a membrane bioreactor and reverse osmosis plant for sustainable and cleaner production", Desalination and Water Treatment, pp. 1-9, 2016.

5. Baydar G., Ciliz N., Mammadov A., "Life cycle assessment of cotton textile products in Turkey", Resources, Conservation and Recycling, Vol. 104, pp. 213-223, 2015.

6. Rakib M. I., Saidur R., Mohamad E. N. A., Afifi M., "Waste-heat utilization-the sustainable technologies to minimize energy consumption in 
Bangladesh textile sector", Journal of Cleaner production, Vol. 142, pp. 1867-1876, 2017.

7. Mokhtar N., Lau W., Ismail A., Kartohardjono S., Lai S., Teoh H., "The potential of direct contact membrane distillation for industrial textile wastewater treatment using PVDF-Cloisite 15A nanocomposite membrane", Chemical Engineering Research and Design, Vol. 111, pp. 284-293, 2016.

8. Qureshi R. F., Qureshi K., Bhatti I., Khatri Z., "Statistical modeling for stability of emulsion liquid membrane for the removal of anionic dyes from textile wastewater", Mehran University Research Journal of Engineering and Technology, Vol. 37, no. 3, p. 631, 2018.

9. Erdumlu N., Ozipek B., Yilmaz G., Topatan Z., "Reuse of effluent water obtained in different textile finishing processes", AUTEX Research Journal, Vol. 12, no. 1, pp. 23-28, 2012.

10. Ozturk E., Koseoglu H., Karaboyacı M., Yigit N. O., Yetis U., Kitis M., "Minimization of water and chemical use in a cotton/polyester fabric dyeing textile mill", Journal of Cleaner Production, Vol. 130, pp. 92-102, 2016.

11. Sharma S., "Energy management in textile industry"m International Journal of Power System Operation and Energy Management, Vol. 2, No. 1, pp. 2, 2012.

12. Oğulata R.T., "Utilization of waste-heat recovery in textile drying", Applied Energy, Vol. 79, No. 1, pp. 41-49, 2004.

13. Ozturk E., Koseoglu H., Karaboyaci M., Yigit N. O., Yetis U., Kitis M., "Sustainable textile production: cleaner production assessment/ecoefficiency analysis study in a textile mill", Journal of Cleaner Production, Vol. 138, pp. 248-263, 2016.

14. Ersayin E., Ozgener L., "Performance analysis of combined cycle power plants: A case study", Renewable and Sustainable Energy Reviews, Vol. 43, pp. 832-842, 2015.

15. Breach P. A., Simonovic S. P., "Wastewater Treatment Energy Recovery Potential For Adaptation To Global Change: An Integrated Assessment", Environmental Management, Vol. 61, No. 4, pp. 624-636, 2018.

16. Vajnhandl S., Valh J. V., "The status of water reuse in European textile sector," Journal of
Environmental Management, Vol. 141, pp. 29-35, 2014.

17. Hatami M., Ganji D., Gorji-Bandpy M., "A review of different heat exchangers designs for increasing the diesel exhaust waste heat recovery", Renewable and Sustainable Energy Reviews, Vol. 37, pp. 168-181, 2014.

18. Wu J.-G., Meng X.-Y., Liu X.-M., Liu X.-W., Zheng Z.-X., Xu D.-Q., Sheng G.-P., Yu H.-Q., "Life cycle assessment of a wastewater treatment plant focused on material and energy flows", Environmental Management, Vol. 46, No. 4, pp. 610-617, 2010.

19. Hussain T., Wahab A., "A critical review of the current water conservation practices in textile wet processing", Journal of Cleaner Production, Vol. 198, p,p. 806-819, 2018.

20. Elahee K., "Heat recovery in the textile dyeing and finishing industry: lessons from developing economies," Journal of Energy in South Africa, Vol. 21, pp. 9-15, 2010.

21. Ulson S. M. d. A. G., Melo A. R., de Souza A. A. U., "Re-utilisation conditions of wastewaters from textiles industries", Resources, Conservation and Recycling, Vol. 49, No. 1, pp. 1-13, 2006.

22. Shaikh M. A., "Water conservation in textile industry", Pakistan Textile Journal, Vol. 58, No. 11, pp. 48-51, 2009.

23. Alanya S., Ozturk E., Morova F., Yetis U., Dilek F., Demirer G., "Environmental performance evaluation of textile wet processing sector in Turkey", Proceedings of the 9th Annual EMAN Conference, Vienna, March 2006.

24. Vatopoulos K., Andrews D., Carlsson J., Papaioannou I., Zubi G., "Study on the state of play of energy efficiency of heat and electricity production technologies", European Commission-JRC Scientific and Policy Reports, Petten, The Netherlands, 2012.

25. Subramanyam S., "Utilization of the waste heat from internal combustion engines," Resources, Conservation and Recycling, Vol. 2, No. 4, pp. 297-304, 1989.

26. Jouhara H., Khordehgah N., Almahmoud S., Delpech B., Chauhan A., Tassou S. A., "Waste heat recovery technologies and applications", Thermal Science and Engineering Progress, Vol. 
6, pp. 268-289, 2018.

27. Haidar J. G., Ghojel J. I., "Waste heat recovery from the exhaust of low-power diesel engine using thermoelectric generators", Proceedings of the 20th IEEE International Conference on Thermoelectrics, Beijing, China, pp. 413-418, 811 June 2001.

28. Barma M., Saidur R., Rahman S., Allouhi A., Akash B., Sait S. M., "A review on boilers energy use, energy savings, and emissions reductions", Renewable and Sustainable Energy Reviews, Vol. 79, pp. 970-983, 2017.

29. Martelli E., Kreutz T. G., Gatti M., Chiesa P., Consonni S., "Numerical optimization of steam cycles and steam generators designs for coal to FT plants," Chemical Engineering Research and Design, Vol. 91, No. 8, pp. 1467-1482, 2013.

30. Wang C., He B., Sun S., Wu Y., Yan N., Yan L., Pei X.", Application of a low pressure economizer for waste heat recovery from the exhaust flue gas in a $600 \mathrm{MW}$ power plant", Energy, Vol. 48, No. 1, pp. 196-202, 2012.

31. U.S. Energy Information Administration, Carbon Dioxide Emissions Coefficients 2016. Available at

http://www.eia.gov/environment/emissions/co2 vol_mass.cfm [Last accessed on August 14, 2020]. 